\title{
A STUDY OF ANTIMICROBIAL ACTIVITY OF POLYPHENOLS DERIVED FROM WOOD
}

Shevelev AB ${ }^{1} \bowtie$ Isakova EP², Trubnikova EV ${ }^{3}$, La Porta N${ }^{4}$, Martens $S^{4}$, Medvedeva OA ${ }^{5}$, Trubnikov DV ${ }^{6}, \mathrm{Akbaev} \mathrm{RM}^{7}$,

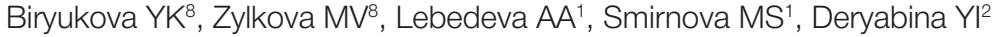

1 Vavilov Institute of General Genetics, Russian Academy of Sciences, Moscow

${ }^{2}$ Bakh Institute of Biochemistry, Research Center of Biotechnology of the Russian Academy of Sciences, Moscow

${ }^{3}$ Kursk State University, Kursk

${ }^{4}$ Fondazione Edmund Mach, San Michele all'Adige, Italy

${ }^{5}$ Kursk State Medical University, Kursk

${ }^{6}$ Prof. Ivanov Kursk State Agricultural Academy, Kursk

7 Skryabin Moscow State Academy of Veterinary Medicine and Biotechnology, Moscow

${ }^{8}$ Chumakov Federal Scientific Center for Research and Development of Immune and Biological Products of the Russian Academy of Sciences, Moscow

Due to the spreading and increasing drug resistance of pathogens, the search for novel antibiotics is becoming ever more important. Plant-derived polyphenols are a vast and promising class of compounds with a potential to fight infectious diseases. Still, they are not routinely used in clinical practice. No reports on the in vivo studies of these compounds have been presented. The aim of our work was to compare the antimicrobial activity of resveratrol (stilbene), dihydroquercetin and dihydromyricetin (flavonols) extracted from the bark and wood of conifers against the dermatophytes Staphylococcus aureus, Pseudomonas aeruginosa and Candida albicans. Using the radial diffusion assay, we established that dihydroquercetin, resveratrol and dihydromyricetin exhibit high activity against $S$. aureus even at the smallest possible concentrations of $0.22,0.15$, and $0.15 \mathrm{mM}$, respectively. In contrast, the highest achievable concentrations of these compounds in the solutions $(21.5,15.5$ and $15.0 \mathrm{mM}$ for dihydroquercetin, resveratrol and dihydromyricetin, respectively) have no effect on the growth of $P$. aeruginosa and C. albicans. These findings suggest that polyphenols derived from conifers could have a potential to be used as a medicine for topical application to treat bacterial infections of the skin caused by S. aureus.

Keywords: polyphenols, flavonoid, stilbene, antimicrobial agents, resveratrol, antimicrobial activity, antioxidants, wood

Funding: this work was supported by the Ministry of Education and Science of the Russian Federation (Subsidy Contract No 14.616.21.0083 since July 17, 2017 ID RFMEFI61617X0083).

$\triangle$ Correspondence should be addressed: Alexei B. Shevelev

Gubkina 3, Moscow, 119991; shevel_a@hotmail.com

Received: 13.06.2018 Accepted: 20.07.2018

DOI: $10.24075 /$ brsmu.2018.040

\section{ИССЛЕДОВАНИЕ АНТИМИКРОБНОЙ АКТИВНОСТИ ПОЛИФЕНОЛОВ ИЗ ДРЕВЕСНОГО СЫРЬЯ}

А. Б. Шевелев ${ }^{1 凶}$, Е. П. Исакова², Е.В.Трубникова ${ }^{3}$, Н. Ла Порта ${ }^{4}$, Ш. Мартенс ${ }^{4}$, О. А. Медведева ${ }^{5}$, Д. В. Трубников ${ }^{6}$, Р. М. Акбаевㄱ, Ю. К. Бирюкова ${ }^{8}$, М. В. Зылькова ${ }^{8}$, А. А. Лебедева ${ }^{1}$, М. С. Смирнова

1 Институт общей генетики имени Н. И. Вавилова РАН, Москва

2 Институт биохимии имени А. Н. Баха, ФИЦ Биотехнологии РАН, Москва

${ }^{3}$ Курский государственный университет, Курск

${ }^{4}$ Фонд имени Э. Маха, С. Микеле аль Адидже, Италия

${ }^{5}$ Курский государственный медицинский университет, Курск

${ }^{6}$ Курская государственная сельскохозяйственная академия имени И. И. Иванова, Курск

7 Московская государственная академия ветеринарной медицины и биотехнологии - МВА имени К. И. Скрябина, Москва

${ }^{8}$ Федеральный научный центр исследований и разработки иммунобиологических препаратов имени М. П. Чумакова РАН, Москва

В связи с выработкой патогенами лекарственной устойчивости к используемым антибиотикам поиск антимикробных агентов нового типа приобретает все большую актуальность. Растительные полифенолы - обширный и перспективный в борьбе с инфекционными заболеваниями класс соединений. Однако они почти не используются в медицинской практике, а результаты их биологических испытаний in vivo в литературе отсутствуют. Целью работы было провести сравнительное исследование антимикробной активности препаратов полифенолов ресвератрола (стильбен), дигидрокверцетина и дигидромерицетина (флавонолы), выделенных из коры и древесины хвойных пород, в отношении дерматофитов: Staphylococcus aureus, Pseudomonas aeruginosa и Candida albicans. В тесте на подавление роста газона индикаторных культур в условиях радиальной диффузии из лунки установлено, что все три соединения проявляют высокую активность в отношении S. aureus: концентрации 0,22 мМ для дигидрокверцетина, 0,15 мМ для ресвератрола и 0,15 мМ для дигидромерицетина превышают предел эффективности. Напротив, в отношении P. aeruginosa и C. albicans даже максимально возможные с учетом растворимости концентрации полифенольных соединений 21,5 мМ, 15,5 мМ и 15,0 мМ не оказывают какого-либо эффекта на рост культур. Полученные данные позволяют рассматривать полифенолы из хвойных растений в качестве перспективного наружного средства для лечения бактериальных инсекций кожи, вызываемых S. aureus.

Ключевые слова: полифенолы, флавоноиды, стильбены, антимикробные средства, ресвератрол, антимикробная активность, антиоксиданты, древесное сырье

Финансирование: исследование поддержано Министерством образования и науки Российской Федерации (Соглашения о представлении субсидии № 14.616.21.0083 от 17.07.2017, уникальный идентификатор RFMEFI61617X0083)

$\bowtie$ Для корреспонденции: Алексей Борисович Шевелев

ул. Губкина, д. 3, г. Москва, 119991; shevel_a@hotmail.com

Статья получена: 13.06.2018 Статья принята к печати: 20.07.2018

DOI: 10.24075/vrgmu.2018.043 
Polyphenols are secondary metabolites massively produced by plants. They have found wide application in the pharmaceutical industry and are routinely used as basic ingredients in complementary medicine. So far, over 8,000 phenolic compounds of plant origin have been identified. They are classified into simple phenols, derivatives of hydroxy cinnamyl and hydroxy benzyl alcohols, flavonoids, stilbenes, and lignans [1]. The largest class of polyphenols is constituted by flavonoids. Their core is formed by a flavan nucleus: a structure consisting of two aromatic rings linked by a chain of three carbon atoms [2]. Flavonoids (chalcones, catechins, anthocyanins, leucoanthocyanins, flavones, flavanones, and flavonols) are found in abundance in bark, flowers, seeds and fruits. Stilbenes, another group of polyphenols, have two benzene rings and are related to flavonoids.

Stilbenes exert antioxidant and antimicrobial activity protecting plants from the harmful effects of phytopathogens, ozone and ultraviolet light. Stilbenes are found in various phyla and in conifers in particular [3]. The most famous representative of stilbenes is resveratrol. Other stilbenes, including pterostilbene, pinosylvin and rhaponticin, have also exhibited a similar type of activity [2].

Functionally, stilbenes and flavonoids belong to a class of phytoalexins, natural antibiotics of plants that protect the latter against infectious diseases and are synthesized in response to bacterial or fungal infections. It is reasonable to assume that phytoalexins will also demonstrate their bactericidal activity in vitro. As a rule, the extracts of herbs rich in flavonoids, such as chamomile, St. John's wort, plantain, and marigold, have a marked antibacterial effect [4]. In recent years, there has been growing interest in phytoalexins stimulated by the challenge of drug resistance and the ability of bacteria to form biofilms normally studied in such important model pathogens as Mycobacterium tuberculosis, Streptococcus pneumoniae, Neisseria gonorrhoeae, and Streptococcus mutans [5]. The most promising polyphenols capable of neutralizing these bacteria are a group of red wine polyphenols responsible for the "French paradox", such as quercetin, kaempferol, resveratrol, and some others [6]. However, despite a surge of interest in this problem, the mechanisms of antibacterial activity of stillbenes and flavonoids remain obscure, although it is known that all subclasses of flavonoids have bactericidal and fungicidal effects [7]. For example, resveratrol inhibits growth of Helicobacter pylori, a pathogen that causes peptic ulcer, in vitro [8], enhances phagocytosis of C. albicans [9] and suppresses phagocytosis of $S$. aureus and $E$. coli; this effect is mediated by the TLR-2 receptors of the innate immunity.

Although there is a huge body of evidence about the antimicrobial activity of plant-derived polyphenols, their use in clinical practice is limited to herbal extracts with unknown or only roughly estimated concentrations of active ingredients. As of today, a few companies and organizations, including TransMIT Gesellschaft für Technologietransfer mbH (Germany) and Favorsky Irkutsk Institute of Chemistry, have launched production of purified polyphenols derived from the bark and wood of conifers. These formulations could be a good option in the treatment of pyogenic and inflammatory conditions caused by infection, considering a rapid spread of multidrug-resistant bacteria.

In this study, we aimed to measure the antimicrobial activity of commercial polyphenols produced from the available raw materials against dermatophytes $S$. aureus, $P$. aeruginosa and C. albicans and to compare it between the studied compounds and with the activity of the antimicrobial ointments for topical application routinely used to treat similar infections.

\section{METHODS}

Resveratrol and dihydromyricetin extracted from conifer wood were courtesy of TransMIT Gesellschaft für Technologietransfer $\mathrm{mbH}$ (Germany). Dihydroquercetin was provided by the laboratory of Favorsky Irkutsk Institute of Chemistry. Quality control by ${ }^{1} \mathrm{H}$-nuclear magnetic resonance spectrometry was performed on the Bruker AM-300 spectrometer (Bruker Daltonics GmbH; Germany). Resveratrol used in the study was a homogenous $100 \%$ trans-isomer.

The studied compounds were dissolved in nonpyrogenic injection-grade normal saline (Escom; Moscow) and passed though Sterile Minisart ${ }^{\circledast}$ syringe filters with polyether sulfone membranes (Sartorius; Germany). Solutions of polyphenolic compounds were stored in 50-ml polypropylene screw-cap tubes at $+4{ }^{\circ} \mathrm{C}$ for 1 month away from direct sunlight.

Levomecol (Nizhfarm; Nizhny Novgorod) is an ointment for topical application used to treat purulent wounds, venous ulcers, inflammation of the skin, and burns. Its active substances are dioxymethyltetrahydropyrimidine (4.0\%) and chloramphenicol $(0.75 \%)$. For our experiments, the ointment was weighted in sterile Eppendorf tubes and diluted tenfold in 96\% ethanol.

Clotrimazole (Glaxo-Wellcome Poznan; Poland) formulated as an ointment containing $1 \%$ of the active substance was diluted in $\mathbf{9 6 \%}$ ethanol in the same way as levomecol was.

\section{Strains of human pathogens}

Pathogenic S. aureus (ATCC 25923), P. aeruginosa (ATCC 27853), and C. albicans (NCTC 2625) were provided by Tarasevich State Institute of Standardization and Control (Moscow). The strains were cultured for 18-20 hours in an agarized meat-peptone broth supplemented with $0.1 \%$ glucose (for bacteria) and $1 \%$ glucose (for C. albicans).

Twenty milliliters of the meat-peptone agar were applied onto 9-cm sterile plastic Petri dishes. The plates were then slightly airdried at room temperature and heated in an air incubator to $+37^{\circ} \mathrm{C}$.

The prepared $1 \%$ agarose was poured into $2-\mathrm{ml}$ glass tubes and cooled down to $40^{\circ} \mathrm{C}$ in the water bath. The melted agarose from each tube was combined with $5 \times 10^{5} \mathrm{CFU}$ of each pathogenic culture, mixed, transferred to a culture plate containing the corresponding growth medium, and the upper layer of the mix was evenly distributed on the plate surface.

One hour after the first layer of the culture was applied, 4-mm wells were made in the agar using a sterile stainlesssteel puncher.

Solutions of polyphenolic compounds with concentrations close to the solubility limit were prepared using $96 \%$ ethanol as a solvent: $0.43 \mathrm{M}$ for resveratrol, $0.31 \mathrm{M}$ for dihydromyricetin, and $0.3 \mathrm{M}$ for dihydroquercetin. These solutions, as well as stock solutions of levomecol and clotrimazole, were then diluted 10-, 100- and 1000-fold in 96\% ethanol. Aliquots of each dilution $(5 \mu \mathrm{l})$ were mixed with $15 \mu \mathrm{l}$ of sterile deionized water. Twenty microliters of the obtained mix were introduced into the wells. Each dilution was tested in three replicates in different culture plates. After the dilutions in the wells were airdried, the plates were placed in the incubator preheated to $+37^{\circ} \mathrm{C}$ and incubated for 40 hours. Clear areas (zones of inhibition) formed in the bacterial and fungal lawns were measured using a pair of calipers.

\section{Statistical processing}

The diameter of a halo in the bacterial/fungal lawn was measured with calipers with an accuracy of $0.5 \mathrm{~mm}$. Every 
Table. Evaluation of in vitro antimicrobial activity of resveratrol, dihydromyricetin and dihydroquercetin against S. aureus, P. aeruginosa, and C. albicans by radial diffusion

\begin{tabular}{|c|c|c|c|c|}
\hline \multirow{2}{*}{ Compound } & \multirow{2}{*}{ Dilution } & \multicolumn{3}{|c|}{ The diameter of the inhibition zone $(\mathrm{mm})$} \\
\hline & & S. aureus & $P$. aeruginosa & C. albicans \\
\hline \multirow{3}{*}{ Dihydroquercetin } & $1 / 10$ & $9.7 \pm 0.4$ & 0 & 0 \\
\hline & $1 / 100$ & $8.3 \pm 0.4$ & 0 & 0 \\
\hline & $1 / 1000$ & $7.7 \pm 0.4$ & 0 & 0 \\
\hline \multirow{3}{*}{ Resveratrol } & $1 / 10$ & $10.0 \pm 0.0$ & 0 & 0 \\
\hline & $1 / 100$ & $8.3 \pm 0.4$ & 0 & 0 \\
\hline & $1 / 1000$ & $7.3 \pm 0.4$ & 0 & 0 \\
\hline \multirow{3}{*}{ Dihydromyricetin } & $1 / 10$ & $11.7 \pm 0.4$ & 0 & 0 \\
\hline & $1 / 100$ & $10.0 \pm 0.0$ & 0 & 0 \\
\hline & $1 / 1000$ & $8.7 \pm 0.4$ & 0 & 0 \\
\hline \multirow{3}{*}{ Levomecol } & $1 / 10$ & $9.3 \pm 0.4$ & $6.3 \pm 0.4$ & 0 \\
\hline & $1 / 100$ & $6.3 \pm 0.4$ & 0 & 0 \\
\hline & $1 / 1000$ & 0 & 0 & 0 \\
\hline \multirow{3}{*}{ Clotrimazole } & $1 / 10$ & $5.7 \pm 0.4$ & 0 & $12.3 \pm 0.4$ \\
\hline & $1 / 100$ & 0 & 0 & $8.3 \pm 0.4$ \\
\hline & $1 / 1000$ & 0 & 0 & $6.0 \pm 0.0$ \\
\hline
\end{tabular}

measurement was done in three replicates in different culture dishes. For a series of 3 measurements, an arithmetic mean and a mean square error were calculated.

\section{RESULTS}

Sizes of the zones of inhibition in the bacterial and fungal lawns are shown in the Table.

Even the highest possible concentrations of the polyphenols tested in our experiment (21.5, 15.5 and $15.0 \mathrm{mM}$, respectively) exhibited zero antimicrobial activity against the gram-negative bacterium $P$. aeruginosa and fungus $C$. albicans. In contrast, the lowest possible concentrations of these polyphenolic compounds $(0.22,0.15$, and $0.15 \mathrm{mM}$, respectively) were effective against the gram-positive $S$. aureus. In vitro activity of dihydromyricetin against $S$. aureus was slightly higher than that of resveratrol and dihydroquercetin.

Levomecol was active against $S$. aureus at the minimal concentration of $24.2 \mathrm{mM}$ and against $P$. aeruginosa at $242.3 \mathrm{mM}$. The lowest active concentration of clotrimazole against C. albicans was below $3.4 \mathrm{mM}$.

\section{DISCUSSION}

The in vitro antimicrobial and antifungal activity of resveratrol and other polyphenols has been reported in several studies [10-12]. Some authors have tested the activity of phenolic compounds against human dermatophytes [13]. The study [14] demonstrates that resveratrol inhibits bacterial phagocytosis by macrophages through the interaction with the TLR2 receptor and the nuclear factor NF-к $\beta$. There is evidence suggesting that resveratrol is capable of inhibiting retinal inflammation experimentally induced by S. aureus [15]. However, so far polyphenols have not been used as an alternative to antibiotics, which raises the question whether research should be continued to obtain a comprehensive description of their specific biological activity.

Our experiments demonstrate that the molar antimicrobial activity of flavonol (dihydromyricetin and dihydroquercetin) and stilbene (resveratrol) against the gram-positive human pathogen $S$. aureus is high: it is even higher than the molar activity of some antibiotics traditionally used for topical application.

In contrast, the activity of those polyphenols against gramnegative $P$. aeruginosa and the pathogenic yeast $C$. albicans is so low that it could not be detected by the assay used in the study. This observation is, however, not consistent with the literature [13] reporting marked resveratrol activity against $S$. aureus and $P$. aeruginosa (in the range between 171 and $342 \mu \mathrm{g} / \mathrm{ml}$, i.e. $39-78 \mathrm{mM}$ ) and the microscopic fungi Trichophyton mentagrophytes, Trichophyton tonsurans, Trichophyton rubrum, Epidermophyton floccosum, and Microsporum gypseum (25-50 $\mathrm{\mu g} / \mathrm{ml}$, i.e. 5.7-11.4 mM).

The obtained data suggest that plant-derived polyphenols, such as dihydromyricetin, have a potential to be used as a medicine for topical application to treat skin infections caused by staphylococci, including their drug-resistant strains. Therefore, further research is needed to investigate the antimicrobial activity of polyphenols using animal models and to assess the toxicity of these compounds towards animal cells, as well as their immunostimulatory and immunosuppressive effects [14, 15].

\section{CONCLUSIONS}

Our study has confirmed the marked antimicrobial activity of resveratrol, dihydromyricetin and dihydroquercetin exerted in vitro at concentrations of $0.15 \mathrm{mM}$ and above. The most pronounced effect was observed for dihydromyricetin. The study suggests a significantly higher bactericidal activity of polyphenols in comparison with the traditionally used levomecol ointment active against $S$. aureus at $24.2 \mathrm{mM}$. 


\section{References}

1. Teplova W, Isakova EP, Klein OI, Dergacheva DI, Gessler NN Deryabina Y. I. Natural Polyphenols: Biological Activity, Pharmacological Potential, Means of Metabolic Engineering (Review). Applied Biochemistry and Microbiology, 2018, Vol. 54 No. 3, pp. 221-237

2. Gudkov SV, Bruskov VI, Kulikov AV, Bobyljov AG, Kulikov DA, Molochkov AV. Biooksidanty. Al'manah klinicheskoj mediciny. 2014; 61 (31): 61-5.

3. Reinisalo M, et al. Polyphenol Stilbenes: Molecular Mechanisms of Defence against Oxidative Stress and Aging-Related Diseases. Oxid Med Cell Longev. 2015: 340520.

4. Mishra A, et al. Bauhinia variegata leaf extracts exhibit considerable antibacterial, antioxidant, and anticancer activities. Biomed Res Int. 2013: 915436

5. Quave CL, et al. Ellagic acid derivatives from Rubus ulmifolius inhibit Staphylococcus aureus biofilm formation and improve response to antibiotics. PLoS One. 2012; 7 (1): e28737.

6. Slobodnikova L, et al. Antibiofilm Activity of Plant Polyphenols. Molecules. 2016; 21 (12): 1717.

7. Andrae-Marobela K, et al. Polyphenols: a diverse class of multitarget anti-HIV-1 agents. Curr Drug Metab. 2013; 14 (4): 392413.

8. Mahady G.B, Pendland SL, Chadwick LR. Resveratrol and red

\section{Литература}

1. Теплова В. В., Исакова Е. П., Кляйн О. И., Дергачева Д. И. Гесслер Н. Н., Дерябина Ю. И. Природные полифенолы: биологическая активность, фармакологический потенциал, пути метаболической инженерии (обзор). Прикладная биохимия и микробиология. 2018; 54 (3): 1-21.

2. Гудков С. В., Брусков В. И., Куликов А. В., Бобылев А. Г. Куликов Д. А., Молочков А. В. Биооксиданты. Альманах клинической медицины. 2014; 61 (31): 61-5.

3. Reinisalo M, et al. Polyphenol Stilbenes: Molecular Mechanisms of Defence against Oxidative Stress and Aging-Related Diseases. Oxid Med Cell Longev. 2015: 340520

4. Mishra A, et al. Bauhinia variegata leaf extracts exhibit considerable antibacterial, antioxidant, and anticancer activities. Biomed Res Int. 2013: 915436.

5. Quave CL, et al. Ellagic acid derivatives from Rubus ulmifolius inhibit Staphylococcus aureus biofilm formation and improve response to antibiotics. PLoS One. 2012; 7 (1): e28737.

6. Slobodnikova L, et al. Antibiofilm Activity of Plant Polyphenols Molecules. 2016; 21 (12): 1717.

7. Andrae-Marobela K, et al. Polyphenols: a diverse class of multitarget anti-HIV-1 agents. Curr Drug Metab. 2013; 14 (4): 392 413.

8. Mahady G.B. Pendland SL, Chadwick LR. Resveratrol and red wine extracts inhibit the growth of CagA+ strains of Helicobacter pylori in vitro. Am J Gastroenterol. 2003; 98 (6): 1440-1.

9. Roupe KA, et al. Pharmacometrics of stilbenes: seguing towards the clinic. Curr Clin Pharmacol. 2006; 1 (1): 81-101.

10. Erlejman AG, Verstraeten SV, Fraga CG, Oteiza PI. The interaction of flavonoids with membranes: potential determinant of flavonoid antioxidant effects. Free Radic Res. 2004; 38 (12): 1311-20.

11. Volynec AP. Novoobrazovanie zashhitnyh fenol'nyh soedinenij pri infekcionnom stresse. V sbornike: Zagoskina NV, Burlakova EB redaktory. Fenol'nye soedinenija: fundamental'nye i prikladnye aspekty. M.: Nauchnyj mir, 2010. S. 168-196.

12. Mishra A, Kumar S, Pandey AK., Scientific validation of the medicinal efficacy of Tinospora cordifolia. The Scientific World Journal. 2013; 2013; ID 292934.

13. Chan MM. Antimicrobial effect of resveratrol on dermatophytes and bacterial pathogens of the skin. Biochem Pharmacol. 2002; 63 (2): 99-104.

14. Iyori $\mathrm{M}$, et al. Resveratrol modulates phagocytosis of bacteria through an NF-kappaB-dependent gene program. Antimicrob Agents Chemother. 2008; 52 (1): 121-7.

15. Marino A, et al. Resveratrol role in Staphylococcus aureusinduced corneal inflammation. Pathog Dis. 2013; 68 (2): 61-4.

wine extracts inhibit the growth of CagA+ strains of Helicobacter pylori in vitro. Am J Gastroenterol. 2003; 98 (6): 1440-1.

9. Roupe KA, et al. Pharmacometrics of stilbenes: seguing towards the clinic. Curr Clin Pharmacol. 2006; 1 (1): 81-101.

10. Erlejman AG, Verstraeten SV, Fraga CG, Oteiza PI. The interaction of flavonoids with membranes: potential determinant of flavonoid antioxidant effects. Free Radic Res. 2004; 38 (12): 1311-20.

11. Волынец А. П. Новообразование защитных фенольных соединений при инфекционном стрессе. В сборнике: Загоскина Н. В., Бурлакова Е. Б., редакторы. Фенольные соединения: фундаментальные и прикладные аспекты. М.: Научный мир, 2010. С. 168-196.

12. Mishra A, Kumar S, Pandey AK., Scientific validation of the medicinal efficacy of Tinospora cordifolia. The Scientific World Journal. 2013; 2013; ID 292934.

13. Chan MM. Antimicrobial effect of resveratrol on dermatophytes and bacterial pathogens of the skin. Biochem Pharmacol. 2002; 63 (2): 99-104

14. Iyori $\mathrm{M}$, et al. Resveratrol modulates phagocytosis of bacteria through an NF-kappaB-dependent gene program. Antimicrob Agents Chemother. 2008; 52 (1): 121-7.

15. Marino A, et al. Resveratrol role in Staphylococcus aureus-induced corneal inflammation. Pathog Dis. 2013; 68 (2): 61-4. 